\title{
PENERAPAN METODE STUDENT ACTIVE LEARNING (SAL) MELALUI MULTI MEDIA POWER POINT UNTUK MENINGKATKAN KEAKTIFAN, KETERAMPILAN BERDISKUSI, DAN HASIL BELAJAR MATEMATIKA
}

\author{
Rustinah \\ SMP Negeri 3 Batanghari, Lampung Timur \\ Email: rustinah.trida@yahoo.com
}

\begin{abstract}
The purpose of this study is find math learning scenarios format with active student learning method of learning mathematics by using multimedia power point to determine how much influence can enhance the activity, discuss the skills and student learning outcomes. Subjects examined or samples studied were students who study at grade students geometry IX.2 SMP Negeri 3 Batanghari, East Lampung. This study occurred during the three months using three cycles. The variables measured in the study include the involvement of the student in the learning process, skills in using media power point and student learning outcomes. Conclusions of this research is that it can increase the creativity of teachers using a variety of learning resources and selection methods that can encourage the creation of a learning process student active learning with contextual approach through multimedia. Can enhance the activity, and fun atusiasme students during the learning process, improve students' skills in solving problems and improve learning outcomes, especially the material geometry.
\end{abstract}

Keywords: activities discussions, learning outcomes, multimedia, SAL

\section{PENDAHULUAN}

Hasil belajar sangat ditentukan oleh keefektivan pembelajaran. Tingkat efektivitas pembelajaran sangat dipengaruhi oleh perilaku pendidik dan perilaku peserta didik. Perilaku pendidik yang efektif, antara lain, mengajar dengan jelas, menggunakan variasi model pembelajaran, menggunakan variasi sumber belajar, antusiasme, memberdayakan peserta didik, menggunakan konteks (lingkungan) sebagai sarana pembelajaran, menggunakan jenis penugasan, dan pertanyaan yang membangkitkan daya pikir dan keingintahuan. Sedangkan perilaku peserta didik mencakup antara lain motivasi/semangat belajar, keseriusan, perhatian, pencatatan, pertanyaan, senang melakukan latihan, dan sikap belajar yang positif. Penelitian Sukestiyarno (2006) yang mengeksperimenkan pembelajaran matematika berbasis media dan teknologi, ternyata menunjukkan semangat siswa untuk mempelajari materi yang sedang dipelajari melalui VCD. Penelitian Kariadinata, (2005) menyatakan bahwa pembelajaran dengan program Computer Based Multimedia merupakan sutu konsep gabungan antara bebrapa komponen seperti gambar, animasi, teks, grafik, suara dan video menjadi suatu yang dikendalikan oleh sistem komputer secara interaktif. Gambar dan animasi 
dapat membuat pengajaran matematika lebih konkrit dan realistik.

Secara geografis, SMPN 3 Batanghari Sebagian besar orang tua siswa bekerja sebagai buruh tani, Kondisi semacam ini berdampak pada kurangnya perhatian orang tua pada masalah pendidikan yang dihadapi siswa, akibatnya motivasi siswa untuk berprestasi dibidang akademik sangat rendah. Demikian juga terhadap yang terjadi pada mata pelajaran matematika.

Keadaan lingkungan sekolah yang minim akan informasi teknologi membuat siswa antusias dengan masuknya multimedia komputer di lingkungan sekolah. Hal ini membuat siswa cenderung mengikuti pelajaran matematika lebih meningkat. Sejalan dengan individu siswa SMP yang menginjak proses dewasa, yang serba ingin tahu dan suka akan tantangan. Hal ini membuat setiap guru harus selalu berinovasi dalam proses belajar mengajar di kelas.

Pembelajaran matematika mengajarkan pemecahan masalah tidak hanya untuk keperluan mata pelajaran matematika saja, tetapi untuk keperluan bidang-bidang ilmu lainnya. Untuk itu dalam pembelajaran matematika sangat diperlukan keterampilan dalam menyelesaian soal - soal matematika dengan berbagai metode. Misalnya proses hitung-menghitung, proses menentukan efisiensi langkah pengerjaan soal (alogaritma), penyelesaian masalah, menentukan logika kebenaran untuk mengambil suatu keputusan dan sebagainya.

Matematika juga berfungsi mengembangkan kemampuan mengkomunikasikan gagasan dengan bahasa melalui model matematika yang dapat berupa kalimat dan persamaan matematika, diagram, grafik atau tabel
(Nurhadi 2002:203). Jadi bagi siswa SMP merupakan kesempatan yang baik dilatih secara kontinu melakukan pemecahan masalah melalui pembelajaran matematika.

Hasil belajar berupa kapabilitas. Setelah belajar siswa memiliki keterampilan, pengetahuan, sikap dan nilai. Timbulnya kapabilitas tersebut adalah dari 1) stimulasi yang berasal dari lingkungan, dan 2) proses kognitif yang dilakukan oleh pembelajar (Dimyati dan Mudjiono 2013:10). Dari pengertian belajar tersebut, terdapat tiga ciri utama belajar, yaitu proses, perubahan perilaku, dan pengalaman.

\section{METODE PENELITIAN}

Penelitian ini dilakukan di SMP Negeri 3 Batanghari kecamatan Batanghari kabupaten Lampung Timur. Adapun subyek penelitian adalah siswa kelas IX.2 SMPN 3 Batanghari. Materi yang digunakan dalam penelitian ini adalah materi bangun ruang. Kegiatan diterapkan dalam upaya menumbuhkan jiwa siswa mempunyai semangat kepemimpinan yang mampu memecahkan masalah yang dihadapi maupun yang dibebankan padanya. Tahapan langkah disusun dalam siklus penelitian. Setiap siklus terdiri atas perencanaan, pelaksanaan, pengamatan, dan refleksi. Penelitian dirancang dalam 3 siklus. Prosedur penelitian terdiri atas 4 tahap : yakni tahap perencanaan tindakan, pelaksanaan tindakan, pengamatan dan refleksi pada setiap siklusnya dan berulang kembali pada siklus berikutnya, mengacu model Hopkins dalam bukunya A Teacher's Guide to Classroom Research $2^{\text {nd }}$ Edition dengan modifikasi (dalam Kusumah dan Dwitagama, 2009: 44) yang di adaptasi untuk dua siklus seperti pada Gambar 1. 
ISSN 2089-8703 (Print) Vol. 6, No. 1 (2017)

ISSN 2442-5419 (Online)

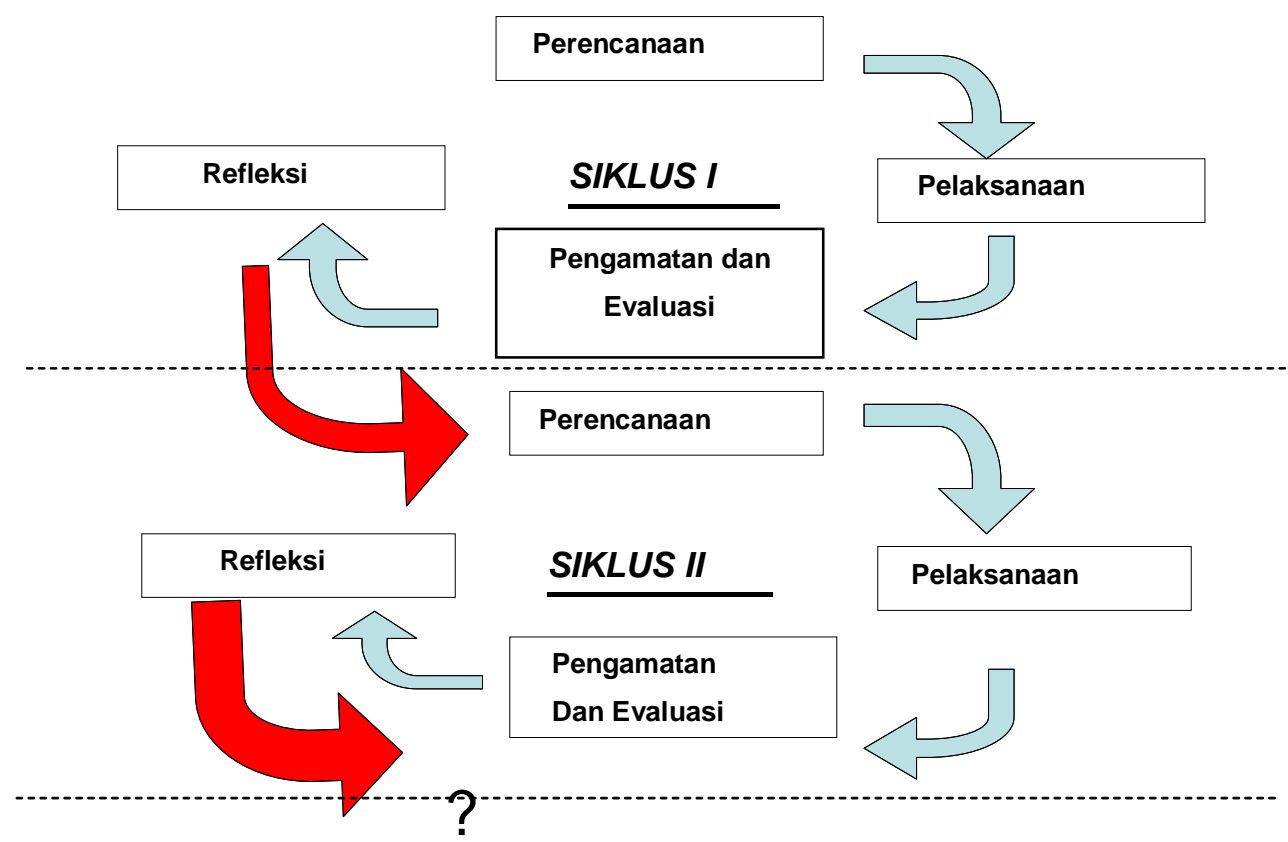

Gambar 1. Siklus Penelitian Tindakan Model Hopkins

Indikator kinerja adalah intrumen pengumpulan data sebagai alat bantu yang digunakan dalam penelitian tindakan kelas. Kriteria keberhasilanpembelajaran yang sesuai dengan tujuan akhir penelitian ini dengan perolehan skor dalam prosentase yang diadopsi dari Sa'adah (2010) adalah sebagai berikut : a) tingkat keaktifan siswa rata-rata selama proses pembelajaran dalam persentase $\geq 80 \%$ : sangat baik; 60\%-79\%: baik; 40\%-59\%: cukup; 20\%-39\%: rendah serta $<20 \%$ : sangat rendah. b) tingkat keterampilan proses siswa rata-rata selama proses pembelajaran dalam persentase: $80 \%$ : sangat baik; 60\%-79\%: baik; 40\%-59\%: cukup; 20\%-39\%: rendah serta $<20 \%$ : sangat rendah. Tingkat keterampilan proses siswa diskoring dengan menggunakan skala likert (1 s.d 5) dengan indikator pencapaian $60 \%$. c) Tingkat keberhasilan belajar siswa dalam persentase 80\%: sangat baik;
60\%-79\%: baik; 40\%-59\%: cukup; 20\%-39\%: rendah serta <20\%: sangat rendah. Tingkat keberhasilan siswa diskoring dengan rentang $0-100$, dengan prosentase hasil tuntas adalag $65 \%$.

Data kualitatif keaktifan dan keterampilan proses dengan pengamatan untuk variabel keaktifan dan keterampilan proses. Data hasil pengamatan dan tes diolah dengan analisis deskriptif untuk menggambarkan keadaan peningkatan pencapaian indikator keberhasilan tiap siklus.

\section{HASIL PENELITIAN DAN PEMBAHASAN}

Berdasarkan data hasil pengukuran variabel keaktifan siswa, maka dilakukan pengolahan data untuk mengukur tingkat keaktifan siswa dengan mempersentasekan jumlah 
keterlibatan siswa pada proses pembelajaran siklus 1 , mencapai 54,29 $\%$ dengan kriteria cukup. Untuk hasil pengukuran variabel ketrampilan proses siswa sebagaimana dilakukan pengolahan data untuk mengukur keterampilan proses siswa dengan mempersentasekan jumlah siswa pada proses pembelajaran pada siklus 1 , mencapai kurang dari 48,57 \% dengan kriteria kurang.Adapan hasil pengukuran variabel tingkat keberhasilan siswa, mencapai ketuntasan dengan persentase 48,57\%, dengan kriteria sedang. Secara lengkap data hasil pengamatan tersebut disajikan pada Tabel 1.

Tabel 1. Data Hasil Pengamatan Variabel Keaktifan, Keterampilan Proses dan Hasil Belajar Siswa Kelas IX SMP Negeri 3 Batanghari (siklus 1)

\begin{tabular}{|c|l|c|c|}
\hline No & \multicolumn{1}{|c|}{ Variabel } & Rata-rata (\%) & Keterangan \\
\hline 1 & Keaktifan & 54,29 & cukup \\
\hline 2 & Keterampilan proses & 48,57 & kurang \\
\hline 3 & Hasil belajar & 48,57 & sedang \\
\hline
\end{tabular}

Berdasarkan data hasil pengukuran variabel keaktifan siswa, maka dilakukan pengolahan data untuk mengukur tingkat keaktifan siswa dengan mempersentasekan jumlah keterlibatan siswa pada proses pembelajaran siklus 2, memcapai 68,57 $\%$ dengan kriteria baik. Untuk hasil pengukuran variabel ketrampilan proses siswa dilakukan pengolahan data untuk mengukur keterampilan proses siswa dengan mempersentasekan jumlah siswa pada proses pembelajaran pada siklus 2, mencapai kdari $60 \%$ dengan kriteria baik.

Adapun hasil pengukuran variabel tingkat keberhasilan siswa mencapai ketuntasan dengan persentase $62,86 \%$, dengan kriteria tinggi. Secara lengkap data hasil pengamatan tersebut disajikan pada Tabel 2 .

Tabel 2. Data Hasil Pengamatan Variabel Keaktifan, Keterampilan Proses dan Hasil Belajar Siswa Kelas IX SMP Negeri 3 Batanghari (siklus 2)

\begin{tabular}{|c|l|c|c|}
\hline No & \multicolumn{1}{|c|}{ Variabel } & Rata-rata (\%) & Keterangan \\
\hline 1 & Keaktifan & 68,57 & baik \\
\hline 2 & Keterampilan proses & 60 & sedang \\
\hline 3 & Hasil belajar & 62,86 & tinggi \\
\hline
\end{tabular}

Hasil pengukuran variabel ketrampilan proses siswa, maka dilakukan pengolahan data untuk mengukur keterampilan proses siswa dengan mempersentasekan jumlah siswa pada proses pembelajaran pada siklus 3, mencapai kurang dari 65,71\% dengan kriteria baik.
Adapun hasil pengukuran variabel tingkat keberhasilan siswa mencapai ketuntasan dengan persentase $60 \%$, dengan kriteria cukup. Secara lengkap data hasil pengamatan tersebut disajikan pada tabel-3.

Pada siklus 1 (Tabel 1) pengamatan dari proses pembelajaran 
menunjukkan bahwa keaktifan siswa masih kurang hanya 54,29 \%, keterampilan proses masih kurang sekali dibawah 48,57 \% dan hasil belajar masih sedang, hanya 48,57 \%. Hal ini kemungkinan disebabkab karena siswa mungkin masih kurang antusias mungkin karena siswa belum dapat beradaptasi dengan model pembelajaran yang selama ini mereka terima. Oleh karena itu pengamat melakukan refleksi terhadap siklus 1 sebagai berikut :

1. Tingkat keaktifan siswa masih dalam taraf cukup dan keterampilan proses masih rendah. Hal ini masih jauh dari target pencapaian keaktifan dan target pencapaian keterampilan proses. Hal ini disebabkan karena baik guru maupun siswa masih dalam taraf penyesuaian. Siswa masih belum terbiasa bekerja sama dalam kelompok. Maka pada siklus berikutnya harus ada peningkatan yang signifikan.

2. Hasil belajar siswa masih rendah dikarenakan siswa belum dapat beradaptasi dalam kelompoknya, sehingga siswa yang diatas rata-rata belum bisa memimpin kelompoknya.

Setelah dilakukan evaluasi dan refleksi pada siklus 1 menunjukkan perubahan yang signifiakan pada siklus 2 , yaitu meningkat menjadi baik ( $68,57 \%$ ) untuk keaktifan dan $60 \%$ untuk keterampilan proses, sedangkan untuk hasil belajar siswa meningkat menjadi $62,86 \%$. Peningkatan tersebut tidak terlepas dari upaya dari guru dan siswa untuk mengjalan fase-fase pembelajaran student active learning dengan media pembelajaran power point. Tetapi peningkatan tersebut masih belum dapat mencapai target keaktifan, keterampilan proses dan hasil belajar siswa. Sehingga pengamat perlu melakukan evaluasi dan refleksi pada siklus 2, yaitu sebagai berikut :
1. Tingkat keaktifan dan keterampilan proses siswa meningkat karena dalam proses pembelajaran guru sudah melaksanakan sebagaian fasefase pembelajaran student active learning. Tetapi semuanya masih perlu ditingkatkan lagi, terutama memberi motivasi kepada siswasiswa yang masih belum kooperatif dalam pembelajaran, dan penyempurnaan pada bagian-bagian yang kurang sempurna.

2. Hasil belajar siswa meningkat karena pada penyusunan rencana pembelajaran diperhatikan kekurangan-kekurangan yang terjadi pada siklus 1 untuk dilakukan perbaiakan pada siklus 2 antara laian :

a. Materi yang disajikan untuk kelompok divariasikan menjadi lima jenis soal yang yang berbeda sehinggga siswa dapat saling bertukar pengalaman dan informasi.

b. Kelompok yang dibentuk guru dengan memperhatikan heterogenitas siswa yaitu mempertimbangkan tingkat kemampuan siswa, jenis kelamin, dan antusiasme siswa pada pelajaran matematika.

c. Sebelum kelompok terbentuk guru terlebih dahulu memperkenalkan aturan-aturan dasar pembelajaran studen active learning dengan media power point, sehingga seluruh anggota kelompok mempelajari materi dengan tuntas.

Pada siklus 3, keaktifan siswa mencapai 77,14 \% ( baik ) sehingga target keaktifan penelitian tindakan kelas yang dilakukan tercapai yaitu 75 $\%$.Untuk keterampilan proses juga menunjukan peningkatan yang signifikan yaitu $65,71 \%$. Sedangkan untuk hasih belajar siswa yang tuntas 
pada siklus 3 mencapai $60 \%$. Hal ini tidak mecapai target ketuntasan belajar yang diharapkan. Refleksi untuk siklus 3 antara lain :

1. Tingkat keaktifan dan keterampilan proses siswa dengan model pembelajaran SAL dengan media power point mencapai target yang diharapkan.
2. Hasil belajar siswa belum mencapai target ketuntasan belajar, hal ini disebabkan oleh indikator soal-soal pada siklus 3 adalah soal analisis sehingga tingkat kesulitannya lebih tinggi dari pada soal siklus 1 dan siklus 2.

Tabel 3. Data Hasil Pengamatan Variabel Keaktifan, Keterampilan Proses dan Hasil Belajar Siswa Kelas IX SMP Negeri 3 Batanghari (siklus 3)

\begin{tabular}{|c|l|c|c|}
\hline No & \multicolumn{1}{|c|}{ Variabel } & Rata-rata (\%) & Keterangan \\
\hline 1 & Keaktifan & 77,14 & Baik \\
\hline 2 & Keterampilan proses & 65,71 & Baik \\
\hline 3 & Hasil belajar & 60 & Cukup \\
\hline
\end{tabular}

\section{KESIMPULAN DAN SARAN}

Penerapan model pembelajaran Student Active Learning (SAL) dengan media Power Point, yang merupakan salah satu aplikasi dari pendekatan kontektual (Contextual Teaching and Learning) dengan kombinasi multimedia pada pembelajaran matematika materi bangun ruang (Tabung, Kerucut dab Bola) di kelas IX.2 SMP Negeri 3 batanghari dapat disimpulkan sebagai berikut :

1. Dapat menigkatkan keaktifan, atusiasme dan menyenangkan siswa selama proses pembelajaran berlangsung.

2. Dapat meningkatkan keterampikan siswa dalam memecahkan soal-soal yang diberikan.

3. Dapat meningkatkan hasil belajar khususnya dalam materi bangun ruang.

4. Dapat meningkatkan kreatifitas guru dengan menggunakan berbagai sumber pembelajaran dan pemilihan metode yang dapat mendorong terciptanya proses pembelajaran student active learning dengan pendekatan kontektual melalui multimedia.

Dari uraian yang telah dikemukakan di muka dan berdasarkan hasil pengamatan, temuan, dan refleksi. Peneliti memberikan beberapa saran diantaranya sebagai berikut:

1. Bagi guru, sesuai dengan saran dalam kurikulum yang berlaku saat ini diharapkan dapat menerapkan variasi model-model pembelajaran yang dapat meningkatkan keaktifan dan ketrmapilan proses dalam pembelajarannya, salah satu alternatif model pembelajaran yang penulis sarankan adalah Student Aktive learning dengan media Power Point. Guru diharapkan untuk terus melakukan evaluasi proses pembelajaran, hal ini penting agar selalu dapat memperbaiki keterbatasan / kekurangan kita. Juga untuk meningkatkan kemampuan dalam menemukan metode dan teknik yang sesuai sehingga tujuan pembelajaran yang telah ditentukan dapat dicapai. 
2. Bagi peneliti, mengingat manfaat yang diperoleh dari penelitian ini, maka diharapkan menjadi pertimbangan bagi peneliti selanjutnya agar ada tindak lanjut dalam rangka untuk meningkatkan dan pengembangan profesi guru.

3. Bagi Sekolah dan Lembaga pendidikan lainnya, agar selalu memberikan dorongan, motivasi, dan sumbangsihnya baik moril maupun materil kepada para guru untuk melakukan penelitianpenelitian yang sederhana yaitu penelitian tindakan kelas, yang sudah barang tentu akan memberikan dampak positif, khusunya bagi guru tersebut dan umumnya bagi sekolah atau lembaga pendidikan lainnya.

\section{DAFTAR PUSTAKA}

Dimyati dan Mudjiono. 2013. Belajar dan Pembelajaran. Jakarta: Rineka Cipta.

Nurhadi. 2002. Pendekatan Kontekstual (Contectual Teaching and Learning). Jakarta: Depdiknas Dirjen Dikdasmen.

Kariadinata, R. 2005. Pengembangan Program Computer Based Multimedia (CBM) dan Peranannya dalam Pembelajaran Matematika. Makalah dalam seminar nasional matematika FMIPA-UPI: Bandung.

Kusumah, Wijaya dan Dwitagama, Dedi. 2009. Mengenal Penelitian Tindakan Kelas. Jakarta: PT. Indeks Permata Puri Media.

Sa'adah. 2010. Analisis Kemampuan Pemecahan Masalah Peserta Didik Yang Menggunakan Pendekatan Open-Ended Di Kelas VII SMP Negeri 1 Cerme Gresik. Gresik: Universitas Muhamammadiyah Gresik
Sukestiyarno, 2006. Penelitian Tindakan Kelas, Penyusunan Proposal: Pelatihan Bimbingan Teknis Pengembangan Akademis Guru SMP dan SMA. Semarang: UNNES. 